\title{
CONSIDERAȚII PRIVIND CADRUL POLITIC ȘI IDEOLOGIC ÎN PRIMUL DECENIU AL REGIMULUI CEAUȘESCU DIN PERSPECTIVA VIEȚII TEATRALE MAGHIARE ${ }^{1}$
}

\author{
Novák Csaba Zoltán
}

DOI 10.46522/CT.2020.02.01

\begin{abstract}
Considerations on the political and ideological framewor in the first decade of Ceausescu's regime in the perspective of Hungarian theatrical life in Romania
\end{abstract}

During the communist era theatre is characterized by a duplicity, a "schizophrenic" situation. On the one hand it continues the "traditional" way of the cultural mission, transmitting values, aesthetic impressions, asking questions about human existence, and on the other hand it serves the regime. Throughout the communist regime, including this period the official Hungarian theatre and culture had a double load. By cultivating the so-called progressive culture (cultural elements that can be framed in the communist ideological discourse) they served the official line of the regime, transmitting direct or indirect communist propaganda, but at the same time, through careful selection they contributed to preserving the tradition and the ethnocultural identity. At the beginning of the 1960s in the domestic and international political context there is a change of cultural policy in Romania. The party addresses a new type

1. Acest studiu a fost realizat în cadrul proiectului de cercetare FDI al Ministerului Educației Naționale, cu titlul „Teatrul român și maghiar din Târgu-Mureș în perioada Ceaușescu 1965-1989“. 
of call, mobilizing intellectuals to build the sovereign communist Romania, to achieve the emancipation of the Romanian socialist nation. This change was the basis of the cultural policy in the early years of the Ceausescu regime. During the years of relative liberalization, the theatre from Romania, including the Hungarian one, benefited from some new opportunities compared to the Stalinist period: new artistic currents other than socialist realism, some openness to contemporary socialist and Western theatre, changes in repertoire politics etc. This opening period will end in the early 1970s, after the publication of the July Theses. The long-term implication of the theses visibly changed the course of the party ideology. Instead of relaxing at the end of the Dej era and the beginning of the Ceausescu era, a new period of ideological constraint has been established. The effects on dramaturgy and repertoires will appear gradually, until the middle of the 70s. It is obvious that it has started a new stage in the life of the Hungarian theatre in Romania, as well. First the ideological constraints will force an attempt to adapt, than the changes in the attitude of the party and in the policy towards the Hungarian minority will place the Hungarian theatre in another hypostasis, that of the struggle for survival.

\section{Keywords:}

theatre, cultural policy, the July Theses, ideology, repertoire, Hungarian theatre, intellectuals

\section{Introducere}

După Cel de al Doilea Război Mondial, sub influența decisivă a factorului de putere sovietică, România, ca şi alte ţări din Europa Centrală, a intrat în sfera de influență a URSS. A început un lung 
proces de sovietizare, de transformare a societății. Viața culturală, artistică, inclusiv cea teatrală a fost supusă la rândul ei unei presiuni politice, pentru a deveni purtătorul ideologiei și al propagandei comuniste. Această presiune ideologică a fost prezentă în diferite forme (în contextul nevoilor politice și ideologice), pe tot parcursul perioadei 1948-1989. Existența teatrului în acest răstimp, ca de obicei în regimurile totalitare, este caracterizată de o duplicitate, de o situație „schizofrenică“: pe de o parte, continuă linia „tradițională“, misiunea culturală, menirea de a transmite valori, impresie estetică, punând întrebări asupra existenței umane, iar, pe de altă parte, slujește regimul, creând cadrul cultural pentru receptarea mesajelor ideologice ale noului regim. Acest echilibru fragil era influenţat, în diferite perioade ale regimului, de creșterea sau descreșterea presiunii politice. În anumite momente (instaurarea regimului și preluarea modelului stalinist în anii 50, turnura ideologică de după 1971, așteptările național-comunismului din anii 80 ), teatrul s-a confruntat cu o constrângere enormă din partea actorului politic, iar în puținele momente de respiro ideologic (anii 60), teatrul a avut posibilitatea de a căuta și de a găsi noi drumuri, modalități de exprimare.

În această perioadă, comunitatea maghiară din România și-a dezvoltat, în limitele condițiilor politice, o viață culturală bogată, bazându-se pe un sistem instituţional bine organizat. Ca și la nivel național, teatrul a jucat un rol important. Teatrele (secțiile) maghiare, alături de centrele de învățământ și de cultură, au fost unii dintre pilonii cei mai importanți ai vieții culturale maghiare din România, atât din perspectiva politicii culturale (teatrul ca instrument politic), cât și din punctul de vedere al identității etnoculturale.

În această lucrare, ne-am propus o analiză a evoluției cadrului general politico-ideologic, în contextul politicii față de minoritatea maghiară din primul deceniu al regimului Ceaușescu. Vom încerca să prezentăm etapele evoluției ideologice, efectul asupra vieții culturale, atitudinea conducerii de partid faţă de intelectualitate, modul in care PCR a gestionat problema culturii. Considerăm că analiza cadrului ideologic și politic este una importantă, pentru că acest factor a trasat, în linii mari, limitele și posibilităţile existenței culturale. Inclusiv teatrul, în mod direct sau indirect, se raporta la acest cadru general ideologic, pentru că trebuia să dea un răspuns la provocările, insistențele puterii, trebuia să se conformeze sau, dimpotrivă, să găsească modul de a se opune, de a minimaliza efectele negative ale ideologiei. 
Așa cum am punctat, acest studiu face parte dintr-un program mai vast de cercetare, alături de acest aspect, vom continua șirul de analize cu studii de caz referitoare la dramaturgie, la politica de repertoriu, tentativele de control politic (organizația de bază a PCR la teatru), cenzură, strategii personale (bazată pe metoda istoriei orale) etc.

În perioada stalinistă, anii 50, punctul de vedere al instanțelor ideologice, noul teatru al României „democrat-populare“ avea ca scop dezvoltarea nivelului cultural şi artistic al unui public din ce în ce mai larg şi orientarea spectatorilor - prin intermediul repertoriului - în spiritul democrației socialiste; iar acest repertoriu trebuia axat pe concepția ideologică definită de conducerea Partidului Muncitoresc Român - Partidul Comunist Român (PMR-PCR), astfel încât să se pună capăt tradiției vechiului teatru (cu teme pretins decadente, mistice, şovine, diversionist-evazioniste) şi să se modeleze un alt profil al publicului. Teatrul era conceput de către conducerea de partid drept o unealtă importantă în lupta ideologică contra rămășițelor clasei burgheze, în educația și în oferirea unui divertisment populației; el era supus unei duble abordări, purificare ideologică și sprijin instituțional. Pe de o parte, în domeniul artei teatrale, a avut loc o revizuire ideologică a dramaturgiei, s-au mărit presiunea politică şi modalităţile de cenzură, a fost preferat realismul socialist importat din Uniunea Sovietică, în câteva cazuri s-au produs epurări în cadrul personalului teatrelor; pe de altă parte, pe lângă teatrele existente, au fost înființate noi instituții cărora i s-a oferit un sprijin material, pentru realizarea scopurilor ,ideologico-culturale“. ${ }^{2}$ Controlul ideologic asupra culturii și al teatrului era exercitat de către diferite instituții de stat, Direcția Generală de Presă şi Tipărituri (DGTP,1949-1975), care, la rândul ei, avea mai multe secții, între care și secția pentru artă, Serviciul pentru Teatru-Filme, secțiile ideologice ale Comitetului Central, Comitetul de Stat pentru Cultură şi Artă (CSCA), care, începând din 1971, devine Consiliul Culturii şi Educaţiei Socialiste (CCES). Cenzura era

2. Cristian Vasile, Politicile culturale comuniste in timpul regimului Gheorghiu-Dej, Editura Humanitas, București, 2011, pp. 186-232; Angelo Mitchievici, Ioan Stanomir, Comunismul INC. Istorii despre o lume care a fost, Editura Humanitas, București, 2016, pp. 15-101. 
concentrată asupra dramaturgiei, a textelor, apariția scenică încă nu se afla sub lupa controlului ideologic, regimul parcă n-a realizat în timp faptul că actul scenic devine, se transformă într-o oarecare măsură într-o nouă creație artistică.

Teatrul maghiar din această perioadă s-a dezvoltat în aceleaşi condiții. La sfârşitul anilor 40 și începutul anilor 50, a avut loc o proliferare instituțională. Maghiarii din Transilvania au beneficiat de șase teatre de stat (sau secții) maghiare: Timișoara, Oradea, Satu-Mare, Cluj, Târgu-Mureș, Sfântu-Gheorghe. Pe tot parcursul regimului comunist, inclusiv în această perioadă, teatrul și cultura oficială maghiară au avut o dublă încărcătură. Prin cultivarea aşa-numitei culturi progresiste (elementele culturale care pot fi încadrate în discursul ideologic comunist), au servit linia oficială a regimului, transmițând o propagandă comunistă directă sau indirectă, dar, în același timp, printr-o selecție atentă, au contribuit la păstrarea tradiției și a identității etnoculturale. Noua cultură maghiară din România comunistă s-a născut din încrucișarea lecturii proletcultiste, menite să legitimeze noua putere și tradițiile culturale, literare din perioada interbelică, marcată de mișcarea populară (nepszolgalat), care concepea producția culturală ca un serviciu adus comunității, sau, mai bine zis, poporului. ${ }^{3}$

În pofida presiunii ideologice, estetica teatrului din primii ani nu diferea mult de cea din perioada interbelică. Prin personalul teatral și mentalitatea lui, prin metodele de lucru, ,rămășițele“ dinaintea Celui de al Doilea Război Mondial și noile structuri coexistau în pofida tuturor încercărilor partidului. ${ }^{4}$ Tot în această perioadă, apare o nouă generație de intelectuali maghiari, care va juca un rol important în organizarea vieții culturale, inclusiv în lumea teatrului. Grupul cel mai important al epocii a fost așa-numitul grup al generației

3. Un exemplu grăitor ar putea fi cultul celor doi matematicieni Bolyai la Târgu-Mureș, care, pe de o parte, erau prezentați ca oameni de știință, erudiți care au luptat împotriva dogmatismului reacționar și a misticismului, dar pentru comunitatea locală maghiară reprezentau și o continuitate în privința moștenirii culturale. Despre acest fenomen, vezi: Stefano Bottoni, Transilvania roșie. Comunismul român și problema națională 1944-1965, Editura ISPMN, Cluj-Napoca, 2010, pp. 179-189.

4. Kötő József, „Politikum és esztétikum. Színház a totalitarizmus markában (1945-1989) [Politicul și estetica. Teatrul în mâinile totalitarismu- 
'68. Printre ei îi găsim pe: Gáll Ernő, Domokos Géza, Hajdu Győző, Sütő András, Bodor Pál, Huszár Sándor etc. Membrii grupului au fost educaţi, mai ales în anii ' 50 -' 60 , când au frecventat programe universitare sau programul de pregătire a cadrelor la universitatea partidului. Cunoșteau bine limba și cultura română, mecanismele de funcționare ale Partidului Comunist și mulți dintre ei chiar participau activ la viața și activitățile partidului. Existența fiecăruia depindea de partid și de stat, nu dispuneau (sau dispuneau doar într-o măsură infimă) de experiențe sociale dinainte de 1945, deci nici de experiențe despre modul în care funcționase societatea înainte de introducerea dictaturii. Cadrele activității lor erau fixate de ideologia serviciului popular. Au fost pregătiţi în doctrina de stânga, au crezut în ideologia comunistă, iar situația lor poate fi caracterizată prin așa-numita identitate duală: loialitatea față de partid și serviciul în slujba propriei comunităţi. Erau persoane care susținuseră PCR prin toate mijlocele existente. În același timp, au considerat că sistemul instituțional minoritar independent era o necesitate. Această tânără generație, legată de originea etnică maghiară, fascinată de promisiunile bolșevismului, de iluziile mișcării de stânga credea în integrarea politico-ideologică fără asimilare. Ca exemplu, poate fi menționată cariera reușită a celui mai cunoscut dramaturg maghiar din această perioadă în România, Sütő Andras. ${ }^{5}$

Piesele reprezentative ale dramaturgiei maghiare contemporane din această perioadă sunt din punct de vedere dramaturgic superficiale, fără adevărate conflicte, schematice: Sütő Andras-Hajdu Zoltán, „Mezítlábas menyasszony“ (Mireasa descălțată), Kiss László-Kováts Dezső, „Vihar a havason“ (Furtună pe munte). La sfârșitul anilor 50, apare posibilitatea limitată a teatrelor de a produce specta-

lui], în Lengyel György (red.), Szinház és diktatúra a 20. században [Teatru și dictatură], Corvina-OSZMI, Budapest, 2011, pp. 278-301.

5. Novák Csaba Zoltán, Epoca de aur? Ceușescu și maghiarii. Politica Partidului Comunist Român față de minoritatea maghiară în perioada regimului Ceaușescu, Editura Curtea Veche, Târgoviște, 2020, pp. 215-238. Despre Sütő Amdrás vezi: (M)ilyen gazdagok vagyunk(?). Sütő András műhelykonferencia. A marosvásárhelyi Művészeti Egyetemen, a Magyar Művészeti kar szervezésében tartott konferencia előadásai, Lázok János (red.), Polis-UArtPress, Kolozsvár-Marosvásárhely, 2015.

6. Kötő József, Politikum és esztétikum...op. cit., pp. 278-301. 
cole puțin mai nuanțate din punct de vedere artistic: Novák Anna, „Kovácsék“, (Familia Kovács), Szabó Lajos, „Menekülés“ (Fuga), Balla Károly, „Vádolom magam“ (Mă autoacuz), Földes Mária, „Hétköznapok“ (Zile obișnuite). ${ }^{6}$

Instituția care a interpretat cu cea mai mare convingere rolul de furnizor de cultură socialistă ca serviciu adus comunității a fost teatrul de la Târgu Mureș, din 1946 Teatrul Secuiesc de Stat. Condus de faimosul regizor Tompa Miklós și dotat cu o distribuţie excelentă, acesta a devenit în câțiva ani nu numai instituţia de prestigiu a oraşului, ci și o mândrie la nivel național, deoarece a demonstrat faptul că se pot întreține activităţi culturale de calitate și din provincie. Teatrul condus de Tompa a funcționat și ca un adevărat atelier artistic, reușind performanța de a se apropia cel mai mult, din punct de vedere artistic și calitativ, de teatrul românesc, implementând teoria lui Stanislavski, care presupune îmbinarea mesajului social cu o adâncă reprezentare psihologică.

Dubla misiune a teatrului maghiar din capitala Regiunii Autonome Maghiare (RAM) era una evidentă: împreună cu filarmonica, a familiarizat generații întregi de cetățeni cu cultura clasică și cea maghiară, funcționând totodată și ca instrument de propagandă la sate, având misiunea de a distrage atenția populației de la influența misticismului religios. Această duplicitate reiese și din documentele de partid care reflectă faptul că liderii de partid, organele de conducere din RAM nu erau întotdeauna mulțumite de rezultatele teatrului din punct de vedere ideologic, considerând că multe dintre piesele reprezentate nu corespund cerințelor ideologice, au un conținut $\mathrm{cu}$ caracter mic burghez. ${ }^{7}$

\section{Anii liberalizării aparente}

Originile și explicația perioadei relativei liberalizări din primul deceniu al regimului Ceaușescu le găsim, într-o oarecare măsură, în evoluția ultimilor ani din epoca Gheorghiu-Dej. Evenimentele politice de după revoluția maghiară din 1956 au schimbat, treptat, cadrul ideologic, atât în contex-

7. Stefano Bottoni, Transilvania roșie..., op. cit., p. 185.

8. Novák Csaba Zoltán, Epoca de aur?..., op. cit., pp. 21-31. 
tul lagărului socialist, cât și ceea cece privește România. Regimul Gheorghiu-Dej a supraviețuit procesului de destalinizare și evenimentelor revoluționare din alte state socialiste (Ungaria, Polonia). Eliminând vechiul grup moscovit, liderul PMR și-a consolidat pozițiile în partid. Pe plan extern România a început o politică de distanțare față de tutela sovietică și a obținut chiar și retragerea trupelor Armatei Roșii de pe teritoriul țării. Întregul proces a culminat cu respingerea în 1964 a așa-numitului plan Valev și cu declarația Comitetului Central al PMR care a subliniat, între altele, teza potrivit căreia fiecare partid comunist este liber să elaboreze propriile directive și propria linie politică. Cu acest document, cunoscut ca „declarația de independență" a României, statul român și-a afirmat, de fapt, independența în cadrul blocului socialist. Prin această declarație, PMR a transformat suveranitatea și autonomia din tabăra socialistă într-o doctrină internă. Controlul ideologic strict și total exercitat asupra întregii societăți a fost contrabalansat de aceste măsuri populare de politică externă (suveranitate față de URSS și o relativă deschidere spre Occident), iar mai târziu, de la începutul anilor '60, de reconciliere parțială cu societatea. Reabilitarea politică și grațierea, din perioada 1963-1965, au fost două dintre cele mai importante inițiative implementate cu intenția de a promova reconcilierea socială parțială. Au fost reabilitați mai mulți scriitori, savanți, mai multe personalități publice care figurau pe listele negre ale partidului. Utilizarea simbolurilor naționale și reinterpretarea istoriei au fost alte elemente importante cu putere de mobilizare în încercarea partidului de a obține sprijinul societății. Conducerea de partid a dat dovadă de un fler politic extrem de rafinat, reușind să capteze și să-și aproprie discursul național românesc, un discurs dinamic și de succes încă de la apariția sa, la mijlocul secolului al XIX-lea. ${ }^{8}$

Toate aceste evenimente, ,împăcarea cu țara“, au marcat începutul unei noi etape și în viața culturală. Emanciparea față de URSS a însemnat automat și o treptată debarasare a elementelor sovietice din cultura românească, o întărire a

9. Ioan Stanomir, „1964: ștafeta nevăzută“, în Paul Cernat, Ion Mano- 
elementului autohton, național, o desprindere de tutela apăsătoare a realismului socialist de tip sovietic. Are loc o schimbare și în comportamentul partidului față de intelectuali. Așa cum am amintit, au loc grațieri, reabilitări politice, după o perioadă de reprimare a elitei intelectuale, urmează o nouă deschidere, o bonomie paternă. PMR adresează un nou tip de chemare, mobilizarea intelectualilor pentru făurirea unei Românii comuniste suverane, pentru realizarea emancipării națiunii socialiste române. Așa cum afirmă Ioan Stanomir, rafinarea discursului și clonarea patriotismului vor fi la originea schimbării la față, care a însemnat, automat, și o schimbare a generațiilor. Vechii luptători au predat ștafeta celor născuți în sânul lumii noi. ${ }^{9}$

Această chemare din partea partidului, acest nou tip de discurs vor fi adresate și către lumea literaturii și a teatrului prin intermediul doctrinelor, al mesajelor de partid. În textele congresului al II-lea al PMR din 1960, alături de vechile lozinci privind lupta împotriva rămășițelor burgheze, idealizarea poporului, a clasei muncitoare, apare și ideea temelor autohtone și prevestirea a unei noi etape în expansiunea socialismului românesc. „Dezvoltând rezultatele pozitive obținute în ultimii ani în lărgirea tematicii și îmbogățirea fondului de idei al literaturii, artei, teatrului, cinematografiei, creatorii noștri au îndatorirea de a făuri opere la nivelul înaltelor exigențe artistice și ideologice ale partidului și poporului. Pentru aceasta se cere în afară de talent, lichidarea a tot ce-1 poate îndepărta pe artist de popor - spirit de castă, individualism, tendințe de a făuri opere pentru uzul unui cerc îngust de aleși, se cere îndeosebi cunoașterea aprofundată a realităților, studierea lor îndelungată, contactul viu permanent al artistului cu oamenii muncii - viitorii eroi ai operelor sale“. ${ }^{10}$

lescu, Angelo Mitchievici, Ioan Stanomir, Explorări în comunismul românesc vol. III, Polirom, București, 2004, pp. 102-137.

10. Congresul al III-lea al PMR, 20-25 iunie 1960, Editura Politică, București, 1960, p. 92.

11. Novák Csaba Zoltán, Epoca de aur?... op. cit., pp. 31-47. 
Venirea la putere a lui Nicolae Ceaușescu va relansa acest tip de abordare și va deschide noi drumuri în evoluția vieții culturale și teatrale. Ceaușescu a fost ales prim-secretar al PMR în data de 22 martie 1965, la scurt timp după moartea lui Gheorghiu-Dej. În 4-5 ani după preluarea puterii, Ceaușescu și-a înlăturat treptat toți adversarii politici și a creat condițiile de politică internă pe baza cărora a putut lansa o nouă direcție socială și economică. În 1965, are loc cel de al IX-lea Congres al PCR care marchează începutul unei noi perioade politice și ideologice. Primii ani după instaurarea lui Ceaușescu la conducerea țării au trecut cu elaborarea, respectiv propagarea noilor principii și directive ideologice propuse de Ceaușescu sau a celor încetățenite deja în timpul lui Gheorghiu-Dej. Printre directivele menționate, se numără cele referitoare la întărirea bazei ideologice și punerea în aplicare a așa-numitei politici de independență, precum și la pregătirea treptată a transformărilor economico-administrative planificate în perioada anterioară. ${ }^{11}$

În domeniul politicii ideologico-culturale noua conducere de partid continuă linia trasată la începutul anilor 60. În documentele congresului, se subliniază faptul că țara a pășit pe o nouă treaptă de dezvoltare (distanțare de trecutul sovietic), aceste noi condiții îi determină pe oamenii de cultură la o nouă abordare a realității. Intelectualilor le este permisă, chiar indicată debarasarea de greșelile trecutului, fiind stimulați să continue linia progresistă a culturii românești și să se ocupe de multiplele „momente importante din istoria patriei noastre care nu și-au găsit încă oglindirea deplină în operele literar-artistice“. ${ }^{12}$ Pentru prima oară în istoria țării de după 1949, apare într-un document oficial posibilitatea de „intensificare a colaborării cu oamenii de cultură și artă din țările socialiste, și din celelalte țări, un contact cu viața culturală contemporană pentru manifestare tot mai intensă a țării noastre în concertul culturii și artei universale“. ${ }^{13}$ „Generozi-

12. Congresul al IX-lea al PCR, 19-14 iulie 1965, Editura Politică, București, 1965, p. 92.

13. Idem.

14. Ibidem. p. 96. 
tatea" noii conduceri în domeniul artei teatrale s-a manifestat și în desființarea protecției unilaterală a realismului socialist: ,... trebuie înlăturată orice tendință de exclusivism sau rigiditate manifestată în acest domeniu. Esențial este ca fiecare artist, în stilul său propriu, păstrându-și individualitatea artistică, să manifeste o înaltă responsabilitate pentru conținutul operei sale, să urmărească ca ea să-și găsească drum larg spre mintea și inima poporului “. ${ }^{14}$

În procesul de consolidare și legitimare a puterii sale, Ceaușescu nu s-a mulțumit cu mesajele ideologice sus amintite. Reașezarea relației cu societatea românească este reflectată și în politica față de intelectuali, față de cultură. Începând din 1965 au loc primele întâlniri cu reprezentanții diferitelor grupuri sociale, așadar și cu scriitorii, cu oamenii de cultură și de teatru. Cu ocazia acestor întâlniri bine organizate și coregrafiate, liderul PCR avea ocazia de a transmite personal noile linii ideologice, de a adresa o chemare personală și, printr-o interacțiune bazată pe o oarecare reciprocitate, de a trasa limitele și posibilitățile ariei de activitate culturală. În data de 19 mai 1965, a avut loc o întâlnire cu reprezentanții vieții culturale, o dezbatere la care au fost invitați și câțiva reprezentanți ai vieții teatrale. $\mathrm{Cu}$ această ocazie, liderul de partid a prezentat și în mod direct noul cadru al vieții culturale. În cazul teatrului, acesta a acceptat că sunt anumite probleme administrative, organizatorice (financiare, funcționarea instituțiilor de teatru etc.) care trebuie rezolvate. Pentru prima oară un lider comunist din România a vorbit direct de o oarecare ruptură față de realismul socialist, despre „lupta între realism și alte curente opuse“, afirmând că sunt acceptate și alte curente de creație. „Fără îndoială, este bine și necesar ca artistul să-și pună în opera de artă toată personalitatea și individualitatea, dar opera sa va fi valoroasă în măsură în care va exprima realitățile în care trăiește“. ${ }^{15}$ Teatrelor li s-a permis schimbul cultural nu

15. P.C.R. și intelectualii în primii ani ai regimului Ceaușescu (1965-1972). Ediție de documente elaborată de: Alina Pavelescu, Laura Dumitru, București, 2007, p. 22.

16. Ibidem, p. 39. 
numai cu țările socialiste ci și, într-o oarecare măsură, cu Occidentul. Ceaușescu n-a ezitat să vorbească nici despre noua interpretare a culturii progresiste, care în privința autorilor, a temelor era mult mai generoasă decât cea din anii 50. Au fost pomenite numele lui M. Eminescu, I. L. Caragiale, M. Sadoveanu, O. Goga, L. Rebreanu.

Din partea reprezentanților din domeniul teatrului și al dramaturgiei, au luat cuvântul Niki Atanasiu, artist al poporului, prim-secretar al Asociației oamenilor de artă din instituțiile teatrale și muzicale, Horia Lovinescu, directorul Teatrului „C. I. Nottara“ și Aurel Baranga. Toți vorbitorii au salutat deschiderea față de literatura universală contemporană, față de schimburile culturale și deschiderea față de tradiția culturală românească. Lovinescu a subliniat problema reînnoirii dramaturgiei contemporane, necesitatea de a regândi organizarea teatrelor (chiar și cu noi festivaluri) și necesitatea noilor interpretări artistice, subliniind că nu este o problemă, dacă apare „un alt mod de a înregistra realitatea“. ${ }^{16}$ Aurel Baranga, cel care ulterior devine unul dintre cei mai influenți oameni de cultură din această perioadă, cu simțul rafinat al poziționării față de noile curente ideologice, a vorbit despre rolul și misiunea ideologică a teatrului: ,...este încă loc pentru marile drame și tragedii, pentru uriașele epopei inspirate din viața partidului și a poporului nostru. Există, de asemenea, loc și pentru marile satire care să polemizeze în mod deschis și combativ“. ${ }^{17}$

$\mathrm{O}$ acțiune similară de recâștigare a încrederii intelectualității maghiare a fost organizarea unei întâlniri între conducerea partidului, la cel mai înalt nivel, și intelectualii maghiari. La iniţiativa liderilor PCR, în data de 28 iunie 1968, cei mai influenți formatori de opinie maghiari (peste 50 de scriitori, poeți, redactori, artiști, cadre didactice) au fost invitați la București să participe la evenimentul organizat după tiparul deja consacrat al întâlnirilor anterioare. Între intelectualii

17. Ibidem, p. 40.

18. Rappaport Ottó (regizor, Cluj), Senkálszky Endre (actor, direc- 
maghiari, îi găsim și pe reprezentanții teatrelor prin directorii, conducătorii celor șase teatre maghiare din Transilvania, respectiv regizori, actori și dramaturgi. ${ }^{18}$ Dat fiind faptul că aria de acoperire a teatrului maghiar din Transilvania era una satisfăcătoare, nu au apărut în această privință probleme administrative, instituționale, de înființare sau de reorganizare. Probleme legate de activitatea teatrelor maghiare au apărut indirect, prin prisma regândirii așa-numitei culturi progresiste maghiare din România, prin intermediul dramaturgiei contemporane maghiare. ${ }^{19}$

Pentru a întări propriile poziții și pentru a scăpa de vechii adversari politici din interiorul partidului, Ceaușescu a inițiat o politică de distanțare pe linie internă față de primele decenii de după Cel de al Doilea Război Mondial. Așadar, alături de ideologia mobilizatoare, chemarea prin patriotismul socialist, apare posibilitatea criticii și a autocriticii, care va fi reflectată și în dramaturgia contemporană. Prin acest gest, prin depistarea greșelilor trecutului, intelectualității umaniste i se oferă, cu generozitate, un nou teritoriu de explorare, ea este investită, post factum, cu misiunea de lampadofor al conștiinței naționale. Dramaturgii contemporani, „inginerii sufletului“, iau parte în rescrierea trecutului apropiat. ${ }^{20}$ Bine-

tor, Cluj), Nagy István (scriitor, Cluj), Farkas István (regizor, Oradea), Vitályos Ildikó (actriță, Oradea), Csíki András (director, Satu Mare), Dukász Anna (actriță, director, Sfântu-Gheorghe), Mag Péter (secretar literar, Timișoara), Sinka Károly (director, Timișoara), Sütő András (scriitor, Târgu-Mureș), Kovács György (actor, Târgu-Mureș), Gálfalvi Zsolt (critic literar, director, Târgu-Mureș), Lohinszky Loránd (actor, Târgu-Mureș). Dintre acești oameni de teatru nu toți erau prezenți la întâlnire, însă numele lor figura în lista celor mai influenți intelectuali maghiari din Transilvania întocmită de către conducerea de partid. Listă despre intelectualii maghiari din România, 25 iunie, 1968. Arhivele Naționale Istorice Române, CC al PCR Secția Propagandă și agitație, dos. 18/1968. ff. 98-102.

19. Novák Csaba Zoltán, Epoca de aur?...op. cit., pp. 85-93

20. Ioan Stanomir, „Simfonia patetică: montaj dramatic, în două acte și un prolog“, în Paul Cernat, Ion Manolescu, Angelo Mitchievici, Ioan Stanomir, Explorări în comunismul românesc vol. I, Polirom, București, 
înțeles, socialismul putea fi contestat numai la nivelul amănuntelor și nu în fond, acest spațiu de dezbatere nu punea in pericol stabilitatea sistemului. Din punctul de vedere al teatrului politic, nu mai este vorba de rigiditatea anilor 50, a sosit timpul pentru a-1 seduce pe spectator cu o variantă mai elaborată a pieselor de partid. ${ }^{21}$

Noua orientare a anilor 60 își pune amprenta și asupra repertoriului teatrelor. Așa cum se stabilit inițial la congresul PMR și cum fusese, apoi, solicitat în mod accentuat de către Ceaușescu personal, dramaturgia contemporană, piesele românești, „originale“ trebuiau să înregistreze o prezență cât mai mare pe scenele teatrelor din România. În această perioadă, a crescut semnificativ numărul pieselor autohtone. De exemplu, în stagiunea 1965-1966, la nivel național, piesele contemporane românești erau prezente cu 166 de spectacole, piesele românești clasice și din perioada interbelică cu 93 de spectacole, piesele din țările socialiste cu 55 de spectacole, iar piesele clasice universale cu 90 spectacole. Alături de piesele autohtone, putem remarca și numărul relativ mare al pieselor din Occident, respectiv 130 spectacole, ceea ce marca politica de deschidere culturală. Din totalul de 534 de spectacole, 259 au fost piese românești, iar din cele 276 de premiere, 135 au fost piese românești. ${ }^{22}$ Proiectul de repertoriu pentru stagiunea 1966-1967 arăta aceeași direcție : piese românești contemporane - 106 premiere, piese românești clasice și din perioada interbelică - 64 premiere, piese din țările socialiste - 12 de premiere, piese din dramaturgia clasică universală - 87 premiere, piese din dramaturgia occidentală contemporană - 64 premiere. În totalitate, 432 titluri, din care 187 românești, 674 de spectacole, din care 328 românești, 333 de premiere, din care 170 românești. Cei mai la modă dramaturgi contemporani în acești ani erau: Aurel

2004, pp. 326-329.

21. Idem.

22. Arhiva Teatrului de Stat Târgu-Mureș, Secția maghiară, cutia 1965, dos. anul 1965. 
Baranga (Sfântu Mitică blajinul în 12 teatre, Adam și Eva, Siciliana, Fii cuminte, Cristofor, Opinia publică în 6 teatre), Paul Everac cu 12 spectacole, Eugen Barbu cu patru piese, Dorel Dorian cu cinci piese, Drăgușanu cu nouă piese. Cei mai jucați clasici erau: V. Alecsandri, L. Blaga, I. L. Caragiale, Alexandru Davila, B. Ștefănescu-Delavrancea, B. P. Hașdeu, T. Mușatescu și Camil Petrescu. Din dramaturgia universal, erau prezenți piesele lui: B. Shaw, W. Shakespeare, Moliere, Aristofan, H. Ibsen, C. Goldoni, A. Cehov și M.Gorki. ${ }^{23}$

Deschiderea culturală din anii 60 a avut un efect simțitor și în evoluția teatrului maghiar din România. După restricțiile ideologice de după înăbușirea revoltei ungare din 1956, are loc, treptat, dezghețul ideologic care va fi reflectat și în repertoriile celor șase teatre. Din fișele de activitate pentru stagiunea 1965-66, reiese faptul că a crescut vizibil numărul spectacolelor și al „pieselor străine“, la Sfântu-Gheorghe (218 românești, 142 străine), la Oradea (56 românești, 180 străine), la Satu Mare (71 românești, 138 străine), la Timișoara (50 românești, 174 străine). Nici în această perioadă, teatrele maghiare nu au abandonat misiunea specifică a instituțiilor minoritare de a face cunoscute valorile culturale maghiare, realizând spectacole fie din literatura clasică, fie din ceea contemporană. La mijlocul anilor 60, aproximativ $20 \%$ din piesele jucate erau maghiare. Cei mai jucați dramaturgi erau: Méhes György, Sütő András, Molnár Ferenc, Madách Imre etc. Dintre dramaturgii contemporani români publicul putea să se întâlnească în teatrele maghiare cu piesele lui Baranga, Everac, I. Hristea, S. Fărcășan, Gellu Naum, M. Sebastian ${ }^{24}$.

În privința pieselor maghiare, în pofida acestor încercări, câteodată într-adevăr sterile, critica maghiară din România nu era mulțumită de numărul și calitatea acestora. Criticul Nagy Pál, din Târgu Mureș, în 1968, vorbea, într-un articol al său, de numărul prea mic al pieselor maghiare (una sau două piese pe an) și solicita mai multe piese din dramatur-

23. Ibidem, dos. anul 1967.

24. Idem. 
gia contemporană maghiară și din cea clasică maghiară și universală. ${ }^{25}$ În ziarul „Vörös Zászló“ din 1970, Csáki Zoltán a polemizat despre necesitatea reînnoirii teatrului maghiar din Târgu-Mureș, subliniind că așteaptă și el creșterea numărului pieselor contemporane. ${ }^{26}$ În revista „A Hét“, într-o analiză mai amplă despre starea teatrului maghiar din România, Kovács Ferenc a subliniat faptul că, din păcate, teatrul maghiar n-a reușit performanța de a se apropia de nivelul teatrelor din București. Teatrele maghiare n-au reușit să profite suficient de posibilitățile deschiderii culturale, regizorii maghiari n-au ajuns să studieze în afara granițelor țării, să intre în contact cu teatrele din occident, totodată nu s-a reușit crearea unei imagini caracteristice teatrului maghiar. Kovács s-a plâns și de slaba situație a criticii maghiare și de puținele contacte pe care le are teatrul maghiar cu cel românesc. ${ }^{27}$ Kötő József consideră că, în privința căutării noilor posibilități și drumuri în teatrul maghiar, trupele din Satu-Mare și Sfântu-Gheorghe au ajuns cel mai departe. ${ }^{28}$

\section{Minirevoluția culturală și efectele sale asupra vieții cultu- rale și teatrale}

La începutul anilor '70, Nicolae Ceaușescu își consolidase deja puterea. El reușise să-și înlăture adversarii politici și, datorită politicii sale externe abile, își sporise substanțial popularitatea atât pe plan intern, cât și pe plan extern. Prin

25. La Târgu Mureș, în perioada 1961-1966, din cele 24 de premiere doar două erau piese maghiare. Ferencz Éva-Keresztes Franciska, Marosvásárhelyi Állami Színház 1961-1978. A magyar tagozaton bemutatott előadások történetének legfontosabb adatai [Teatrul de Stat Târgu-Mureș 1961-1978. Datele cele mai importante ale pieselor prezentate la secția maghiară], Marosvásárhelyi Nemzeti Színház-Kutatóközpont, 2017, pp. 26-91.

26. Csáky Zoltán, A szinház közügy [Teatrul este de interes public], „Vörös Zászló“, nr. 23/1970.

27. Kovács Ferenc, Valamit tenni kell [Trebuie făcut ceva], „A Hét“, nr. 9/1970.

28. Kötő József, Politikum és esztétikum...op. cit., pp. 278-301. 
reforma administrativă, a fost reorganizat teritoriul țării în județe, puse sub conducerea prim-secretarilor loiali conducerii de partid, mai eficiente din punct de vedere economic. Comitetele oamenilor muncii de diferite naționalități, Frontul Democrației și al Unității Socialiste au creat noi forme de control social, dar și noi canale de mobilizare. Congresul al X-lea, din 1969, s-a încheiat cu succesul total al lui Ceaușescu. $\mathrm{Au}$ fost realizate toate condițiile necesare pentru accelerarea punerii în practică a proiectelor grandioase de transformare socială și economică elaborate la nivel teoretic în anii '60, cum erau proiectele de industrializare, de sistematizare a orașelor și a satelor, crearea națiunii socialiste omogene.

Primele semnale de alarmă în privința unei eventuale turnuri în viața ideologică și culturală pot fi depistate în materialele celui de-al X-lea Congres al PCR, din 1969. Criticile aduse vieții culturale prevesteau deja nemulțumirile conducerii de partid față de viața culturală și au trasat hotărât liniile și limitele posibilităților în privința creațiilor artistice: „Se întâmplă însă ca unele lucrări literare sau artistice să fie considerate cu atât mai elevante și mai valoroase cu cât sunt mai puțin accesibile și mai de neînțeles publicului, maselor largi, cu cât se îndepărtează mai mult de problemele vieții, de realitățile lumii în care trăim. [...] Desigur, noi suntem partizanii libertății de creație și orânduirea noastră asigură condiții de manifestare deplină a personalității și a talentului scriitorilor, artiștilor ca și tuturor cetățenilor patriei. Dar noi concepem libertatea de creație în accepțiunea filozofică pe care marxismul o dă necesității istorice înțelese “. ${ }^{29}$ Chemarea către scriitori, artiști în general, prefigura terenul din ce în ce mai limitat pentru temele creațiilor artistice: „Ceea ce vi se cere, tovarăși, este să pătrundeți în adâncul existenței poporului și, înțelegând năzuințele sale, eforturile și lupta sa eroică, să înfățișați grandioasa frescă a României socialiste. Redați prin graiul minunat al artei freamătul creator al poporului, care, transformând

29. Congresul al X-lea al PCR, 6-12 august 1969, Editura politică, București, 1969, 73. p. 
prin munca sa eroică înfățișarea țării, se transformă pe sine însuși. Nu uitați niciodată menirea artei noastre este de a înnobila omul, de a-1 inspira spre noi fapte mărețe, spre realizarea idealurilor socialismului și comunismului““. ${ }^{30}$

La ședința plenară a CC al PCR, din iulie 1971, Nicolae Ceaușescu a ținut un discurs răsunător despre îmbunătățirea activității politico-ideologice și educația membrilor de partid în spiritul marxismului, care a rămas în istorie sub numele de „tezele din iulie“. Ceaușescu și-a prezentat tezele la ședința CC, din 6 iulie 1971. Este data la care a fost lansată în România așa-numita „minirevoluție culturală“. Tezele propuneau amestecul tot mai mare în viața politico-ideologică și culturală: educație ideologică și îndoctrinare mai amplă și mai profundă, redimensionarea propagandei, selecție mai riguroasă a cadrelor de partid, creșterea mobilizării sociale, excluderea curentelor filozofice și culturale occidentale din media națională și înăsprirea cenzurii socialiste. ${ }^{31}$

Plenara Comitetului Central al PCR, în 3-5 noiembrie 1971, a fost dedicată aproape exclusiv vieții culturale. Au fost trasate principalele linii ideologice în cadrul cărora a fost văzută și concepută viața culturală de către conducerea de partid. În discursul lui, Ceaușescu a evidențiat explicit că, în perioada 1971-1975, țara a ajuns într-o nouă etapă, cea a făuririi socialiste multilateral dezvoltate și ca atare totul, inclusiv cultura, trebuie subordonat acestor proiecte de țară. A fost lichidată burghezia, a fost făurită economia socialistă, s-au produs mari transformări în structurile sociale, a avut loc o adevărată revoluție culturală, în acest domeniu totul trebuia subordonat formării omului nou. ${ }^{32}$

Liderul de partid a lansat o critică dură asupra vieții culturale din anii precedenți: lipsuri serioase s-au manifestat în îndrumarea activității literar-artistice, s-a recurs de multe ori la unele teze generale, rupte de viața poporului, au apărut o se-

30. Idem.

31. Novák Csaba Zoltán, Epoca de aur? ... op. cit., pp. 125-128

32. Plenara CC al PCR, 3-5 noiembrie 1971, Editura Politică, București, 1971, pp. 11-24. 
rie de manifestări de rigiditate, închistare, formalism, au fost importate o serie de filme și alte lucrări artistice sau literare de un slab nivel artistic, cu un conținut ideologic-educativ dăunător. ${ }^{33}$ Abandonând total indulgența anilor precedenți, Ceaușescu a trasat o linie militantă în stilul stalinist pentru artă și cultură. „Avem nevoie de o artă izvorâtă din realitățile națiunii noastre, care să fie suflet din sufletul poporului..., oamenii vor să afle din romane, poezii, piese de teatru, opera, din cântece cum au luptat comuniștii și alți antifasciști și democrați, cum au înfruntat închisorile, lagărele, moartea

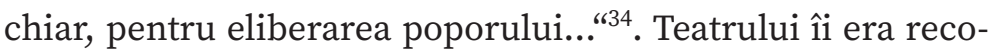
mandată reîntoarcerea la transmiterea mesajului revoluționar: „De asemenea, pe scenele teatrelor noastre, a operei trebuie să-și facă loc lucrări de toate genurile, dar și lucrări contemporane, cu caracter revoluționar, militant, contribuindu-se și pe această cale, în spiritul tradițiilor noastre progresiste, la educarea maselor largi populare“. ${ }^{35}$ Dumitru Popescu, principalul responsabil pentru viața culturală sublinia faptul că este de nepermis ca artistul să se lasă pradă ,jocului gratuit al fanteziei“. Unul dintre cei mai conformiști oameni de cultură și dramaturgi, persoana ale cărui piese erau jucate aproape în toate teatrele din România, Aurel Baranga a recunoscut repede pulsul noilor provocări, în discursul lui subliniind că poporul disprețuiește stările de sincopă intelectuală, de brutalitate, de violență și de intoleranță și că „Noi trebuie să propunem poporului nostru modele de eroi demni de a fi urmați și trebuie să prezentăm poporului nostru anti-modele, adică acele tipuri degradate și insultătoare, pentru condiția umană, care trebuie stârpite din conștiința noastră și a semenilor noștri, cu un ceas mai devreme“. ${ }^{36}$

După câțiva ani de respiro, de pe pozițiile socialismului, literatura și arta erau chemate să biciuiască tot ceea ce se opunea socialismului. Începând din 1971, Ceaușescu introduce

33. Ibidem, pp. 25-27

34. Ibidem, p. 68.

35. Ibidem, p. 69.

36. Ibidem, p. 121. 
treptat noi tipuri de discurs, noi orientări economico-sociale și cultura avea obligația să urmărească aceste etape, trebuia să se orienteze în funcție de aceste fenomene, cu o misiune bine definită. Coexistența a două arte, angajată și burgheză, reacționară, pe teritoriul aceluiași stat socialist este inadmisibilă. Tezele din iulie pot fi concepute ca un ghid de exorcizare a demonilor ce amenință fericirea cetății zidite de partid. Perioada când s-a vorbit de greșeli a luat sfârșit, are loc tribalizarea existenței omului muncii: blocul, cartierul, echipa de fotbal, uzina. Partidul considera un pericol real faptul că, lipsiți de tutela ideologică și de ghidajul comunist, elevii, studenții pot deveni sensibili la cântecul de sirenă al reacțiunii proteice. $^{37}$

Primul conflict între gardienii ideologiei și o trupă teatrală are loc în București, și nu la periferie. În 30 septembrie 1972, „Scânteia“ a reprodus un comunicat prin care era anunțată suspendarea spectacolului regizat de Pintilie: Biroul Consiliului Culturii și al Educației Socialiste a hotărât suspendarea spectacolului [Revizorul] și interzicerea de a fi reprezentat pe vreo altă scenă din țară într-o asemenea adaptare şi va lua măsuri, pentru ca astfel de manifestări să nu mai aibă loc în viaţa culturală din România. ${ }^{38}$ Piesa a fost interzisă (în 1971 și în URSS) din motivul că aducea critici la adresa conducerii de partid și transmitea aluzii la vizitele de lucru ale liderilor de partid. Acest caz a oferit terenul de practică privind interpretarea și aplicarea tezelor. După acest incident, s-au luat primele decizii împotriva teatrelor, de după apariția tezelor.

În 5 octombrie, după cazul Revizorului de la teatrul Bulandra, a avut loc o ședință a Secretariatului CC al PCR. Ceaușescu era foarte nemulțumit de ceea ce s-a întâmplat la Bulandra cu piesa Revizorul și de activitatea CCES care nu-și însușise în mod corespunzător documentele plenarei din 1971. „Nu se

37. Ioan Stanomir, „Un pământ numit România“, în Paul Cernat, Ion Manolescu, Angelo Mitchievici, Ioan Stanomir, Explorări în comunismul românesc vol. III. op. cit., p. 263.

38. Cristian Vasile, Viața intelectuală şi artistică în primul deceniu al regimului Ceauşescu, 1965-1974, Editura Humanitas, București, 2016, pp. 86-118. 
poate tolera în continuare actuala situație care există în teatre. În acest sector de activitate nu s-a făcut cotitura dorită, trebuie odată să terminăm cu politica aceasta mioapă lipsită de principialitate“.$^{39}$ Era nemulțumit de numărul pieselor românești jucate și a pomenit și de problema autofinanțării teatrelor, arătând drept exemplu cazul teatrului din Riga. Șirul vinovaților era unul forte lung: principalul responsabil, Dumitru Popescu, secretarul de partid de la organizația de bază de la Bulandra, Toma Caragiu, conducerea teatrului, regizorul etc. Concluzia trasă de liderul PCR prevestea nori negri pe deasupra teatrelor din România. Iată numai câteva idei punctate: piesa lui Gogol este una progresistă, dar ea fost denaturată prin felul în care a fost pusă pe scenă, în funcția de director să nu fie numiți numai artiști, organizarea unor dezbateri cu directorii teatrelor, reducerea numărului locurilor la institutele de teatru, problema autofinanțării teatrelor, iar în privința cenzurii, „Să se introducă practica organizării unei avanpremiere a tuturor spectacolelor noi la care să participe activul de partid în vederea prevenirii în viitor a unor neplăceri“. ${ }^{40}$

S-a realizat și un „plan de măsuri privind îmbunătățirea activității Consiliului Culturii și Educației Socialiste, a instituțiilor de spectacol și a presei culturale“: dezbaterea cu întregul colectiv la Teatrul „Bulandra“; CCES va analiza activitatea desfășurată; dezbateri cu activul de partid din instituțiile de artă; măsuri pentru fiecare instituție pentru îndeplinirea sarcinilor ideologice; program educativ în fiecare instituție pentru implementarea hotărârilor plenarei din 1971; CCES va analiza activitatea cadrelor de conducere din teatre, unde va fi cazul se vor lua măsuri; CCES va prezenta propuneri conducerii de partid privind îmbunătățirea activității economico-financiare a instituțiilor de spectacole; CCES - ședințe de lucru cu toți criticii de artă, îndrumare pentru ei și instruire poli-

39. P.C.R. și intelectualii în primii ani ai regimului Ceaușescu...op. cit., p. 324.

40. Ibidem, pp. 328-329. 
tică și ideologică; pregătire ideologică și pentru reprezentanții presei; „se va intensifica controlul CCES asupra modului în care se realizează repertoriul aprobat pentru fiecare stagiune, urmărindu-se concepția punerii în scenă până la finalizare ei în spectacol. Înainte de premiera cu public se va organiza de către fiecare instituție, pentru fiecare spectacol de teatru, operă, balet, estradă, operetă și pentru fiecare nou film artistic de lung metraj românesc un spectacol de avanpremieră cu invitați din rândul activiștilor de partid și de stat, al oamenilor de cultură proeminenți, al criticilor de artă“. 41

După aceste prime semnale, s-au autosesizat și câțiva oameni din zona teatrului maghiar. Iată cum și-a făcut autocritica directorul teatrului de stat din Târgu Mureș, Csorba András: „Repertoriul nostru a avut și piese mai slabe, piese născute din filozofii diferite de principiile marxist-leniniste, piese care reflectă o perspectivă mic-burgheză și care creionează o imagine falsă a lumii în care trăim și vorbesc despre atitudini de viață greșite sau inferioare... Noi suntem conștienți, și documentele de partid ne reamintesc de faptul că de fapt arta înseamnă politică. A crea ceva artistic, însemnă a face politică“ - a subliniat directorul la o ședință organizată de către Comitetul Județean de Partid, condus de primul secretar județean, Nicolae Vereș. Tot cu ocazia acestei ședințe, cel mai cunoscut dramaturg maghiar din România, Sütő András a criticat modul de interpretare și de regizare al lui Harag György. „Am vorbit și despre câteva probleme de interpretare în cazul teatrelor. Este aici cu noi tovarășul Harag, care ne-a promis că va regiza piesa muncitorească a lui Nagy István, o piesă despre care tineretul ar fi afirmat că este o capodoperă a dramei absurde. Bătrânul scriitor era să leșine când a citit despre propria lucrare că este una absurdă. Tovarășul Harag a considerat că este benefic să prezinte această piesă într-o viziune modernă, considera că prezentarea realistă nu mai este la modă. Sunt și alții, și în literatură și în domeniul criticii, care consideră că o piesă poate fi numită una reușită nu-

41. Ibidem, pp. 331-332. 
mai dacă oamenii se miră și nu înțeleg nimic“". ${ }^{42}$ Cunoscutul scriitor și dramaturg a criticat în continuare regizările în stil modern, jocul actorilor, a afirmat că teatrele, regizorii exagerează când consideră că o piesă este una reușită doar din cauză că are cheltuieli mari sau că sunt prezente personalități cunoscute și se organizează banchetele după spectacol. ${ }^{43}$

Din ancheta din 1972 despre teatrul lui Szőcs Kálmán în ziarul „Vörös Zászló“ reiese încercarea conducerii de teatru de a se acomoda, cel puțin la nivel retoric, la noile cerințe ideologice. Directorul Csorba András a afirmat că noul repertoriu a fost conceput cu grijă, luându-se în considerare documentele de partid. În retorica „spectatorilor“ întrebați de preferințele și așteptările lor de la teatru, regăsim elementele directivei oficiale. Bartha Pál, funcționar public dorea niște piese în care omul să își recunoască rezultatele de producție, colegii de muncă și a manifestat nemulțumirea cauzată de lipsa pieselor scrise de Baranga de pe scena teatrului. Muncitorul Antal József dorea și el piese autohtone, alături de cele clasice. Borda Dorin, bibliotecar, a afirmat că dramaturgia autohtonă este în cea mai prolifică etapă, ,ar fi bine ca dramaturgii să acorde o atenție mai sporită schimbărilor permanente din viața socială și spirituală“ “. ${ }^{44}$

La început, „tezele din iulie“ au fost privite ca o turnură ideologică și nu ca un semn care prevestea o nouă direcție politică. O mare parte a intelectualilor a crezut, în această primă perioadă, că va putea să se adapteze formal la cerințele noii turnuri ideologice și că aceasta va putea fi dejucată, cu excepția anumitor opere literare, piese de teatru sau teme de interes general. Implicațiile pe termen lung ale tezelor au schimbat vizibil cursul ideologiei de partid. În locul relaxării de la sfârșitul epocii Dej și începutul epocii Ceaușescu, s-a in-

42. Arhivele Naționale Române, Direcția Județeană Mureș, fond Comitetul Județean de Partid Mureș, dos 2/1971, ff. 20-64.

43. Idem.

44. „Vörös Zászló“, 206/1971. 
stituit acum o nouă perioadă de constrângere ideologică. Punerea în practică a noului control ideologic va avea consecințe tot mai nefaste pentru întreaga societate românească, mai ales de la sfârșitul anilor'70. Efectele asupra dramaturgiei și a repertoriilor vor apărea treptat, până pe la mijlocul anilor 70 . Este evident faptul că a început o nouă etapă și în viața teatrului maghiar din România. Pentru început, constrângerile ideologice vor forța o încercare de adaptare, iar schimbările atitudinii partidului și în privința politicii față de minoritatea maghiară va plasa teatrul maghiar într-o altă ipostază, într-o luptă de supraviețuirea.

\section{Bibliografie:}

BotToni, Stefano, Transilvania roșie. Comunismul român și problema națională 1944-1965, Cluj-Napoca, Editura ISPMN, 2010.

Cernat, Paul; Manolescu, Ion; Mitchievici, Angelo, Stanomir, Ioan, Explorări în comunismul românesc, vol. III, București, Polirom, 2004.

CERnAT, Paul; Manolescu, Ion; Mitchievici, Angelo, Stanomir, Ioan, Explorări în comunismul românesc, vol. I, București, Polirom, 2004.

CONGRESUl al III-lea al PMR, 20-25 iunie 1960, București, Editura Politică, 1960.

Congresul al IX-lea al PCR, 19-14 iulie 1965, București, Editura Politică, 1965.

CONGRESUl al X-lea al PCR, 6-12 august 1969, București, Editura politică, 1969.

CSÁKY Zoltán, A színház közügy [Teatrul este de interes public], „Vörös Zászló“, nr. 23/1970.

FERENCZ Éva-Keresztes Franciska, Marosvásárhelyi Állami Színház 1961-1978. A magyar tagozaton bemutatott előadások történetének legfontosabb adatai [Teatrul de Stat Târgu-Mureș 19611978, Marosvásárhelyi Nemzeti Színház-Kutatóközpont, 2017, pp. 26-91.

KöTő József, „Politikum és esztétikum. Színház a totalitarizmus markában (1945-1989)“ " Politicul și estetica. Teatrul în mâinile totalitarismului], în Lengyel György (red.), Színház és diktatúra a 20. században [Teatru și dictatură], Budapest, Corvina-OSZMI, 2011. 
KovÁcs Ferenc, Valamit tenni kell [Trebuie făcut ceva], „A Hét“, nr. 9/1970.

LÁzoK János (ed.) Sütő András műhelykonferencia. A marosvásárhelyi Művészeti Egyetemen, a Magyar Művészeti kar szervezésében tartott konferencia előadásai, Kolozsvár-Marosvásárhely, Polis-UArtPress, 2015.

Mitchievici, Angelo, Stanomir, Ioan, Comunismul INC. Istorii despre o lume care a fost, București, Editura Humanitas, 2016.

NovÁK Csaba Zoltán, Epoca de aur? Ceușescu și maghiarii. Politica Partidului Comunist Român față de minoritatea maghiară în perioada regimului Ceaușescu, Târgoviște, Editura Curtea Veche, 2020.

P.C.R. și intelectualii în primii ani ai regimului Ceaușescu (19651972). Ediție de documente elaborată de: Alina Pavelescu, Laura Dumitru, București, 2007.

PlenaRA CC al PCR, 3-5 noiembrie 1971, Editura Politică, București, 1971

VASILE, Cristian, Politicile culturale comuniste în timpul regimului Gheorghiu- Dej, București, Editura Humanitas, 2011.

VASILE, Cristian, Viaţa intelectualã şi artisticã în primul deceniu al regimului Ceauşescu, 1965-1974, București, Editura Humanitas, 2016. 